\title{
"No nation wanted it so much": Beckett, Swift and Psychiatric Confinement in Ireland
}

\author{
Feargal Whelan \\ Trinity Centre for Beckett Studies, Trinity College Dublin, Ireland
}

Copyright (c) 2019 by Feargal Whelan. This text may be archived and redistributed both in electronic form and in hard copy, provided that the author and journal are properly cited and no fee is charged for access.

\begin{abstract}
Samuel Beckett displays an interest in portraying figures normally regarded as insane within their communities, and who are frequently depicted interacting with institutions of mental care. Taking the representation of three asylums in three separate works, this paper aims to explore a developing and complicated meditation on the subjects of mental health and incarceration by the author. Beckett's recurring reference to Jonathan Swift and the constant presence of sexual anxiety in these narratives allows him to produce a nuanced critique of the development of modes of confinement in the emerging Irish state.
\end{abstract}

Key Words. Beckett, Jonathan Swift, Biopolitics, Mental Health, Irish Free State.

Resumen. Samuel Beckett muestra interés en presentar individuos normalmente considerados como dementes dentro de sus comunidades y que suelen ser representados interactuando con instituciones de salud mental. El presente artículo tiene como objetivo explorar la meditación beckettiana acerca de la salud mental y la encarcelación tomando como referencia la representación de tres psiquiátricos en tres obras diferentes. Las recurrentes referencias a Jonathan Swift por parte de Beckett y la constante presencia de una preocupación por lo sexual en estos textos, le permite producir una crítica matizada de la evolución de los modos de reclusión en el incipiente estado irlandés.

Palabras clave. Beckett, Jonathan Swift, biopolítica, salud mental, Estado Libre Irlandés.

The depiction of social outsiders whose behaviour would commonly class them as insane is a constant feature of Samuel Beckett's work, from More Pricks than Kicks (1934) to the tormented narrators of late works, such as Not I (1973). Although the earliest portrayals predate his own period of psychoanalysis with Wilfred Bion at the Tavistock Clinic in London in 1934-5, it is clear that his personal experiences there, and the treatment he 
received, provided a framework for meditating on the nature of asylums and the accepted social manner of dealing with those declared outside the norms of behaviour. His own social isolation, and its acceptance as a "problem", was key to his understanding of "mental illness", as he explained to Thomas MacGreevy in March 1935 following his treatment:

For years I was unhappy, consciously \& deliberately ... But in all that there was nothing that struck me as morbid. The misery and solitude and apathy and the sneers were the elements of an index of superiority and guaranteed the feeling of arrogant 'otherness', which seemed as right and natural and as little morbid as the ways in which it was not so much expressed as implied. (Knowlson 179)

Beckett underwent the treatment at the suggestion of his friend and schoolmate, Geoffrey Thompson, who trained at the Tavistock in 1935, before securing employment at The Royal Bethlehem Hospital (Knowlson 171-82).

Beckett attended his sessions as an out-patient and was therefore never admitted to an institution or asylum, though it is apparent that he took a particular interest in how treatment was administered. According to his wife Ursula, "(Thompson) took Sam, dressed in a white coat, around the Bethlem to see the patients ... He was a bit of a loony and wanted to see the other loonies" (Knowlson, Remembering 72). Leaving aside the derogatory terminology (though Beckett uses the term loony in the short story, "Fingal") it is apparent that he identified with the inmates and as such was interested in their conditions and treatment. It is also crucially important to understand Beckett being at one and the same time a patient (a loony among loonies) and an outside authority figure (a white coat wearer) as this colours the narratives which he develops later in which the binaries of sane/insane and jailer/prisoner become undermined.

The three asylums which are depicted in detail in Beckett's prose, the real-life Portrane Asylum (later St. Ita's Hospital) in "Fingal" (1934), the fictional Magdalen Mental Mercyseat in Murphy (1938), and the real-life House of St John of God in Malone Dies (1951), demonstrate an interest by the author in meditating on the treatment of the insane in a highly complicated way with reference to changing practices of confinement at the time, and also in the unfolding process of social care in the developing Irish Free State. I argue that the triangulation of madness, sexual neurosis and physical confinement, which is first suggested in "Fingal" and is immediately connected to the private life of Jonathan Swift, provides a complicated motif for Beckett's depiction of the institutional treatment of madness. Over the course of the three novels, Beckett refines his narrative, I suggest, so that by the end of Malone Dies, he provides a multi-layered commentary on broader societal implications of institutionalisation in Ireland as well as a critique of the role played by Swift in its provision.

\section{"Fingal"}

On 26 December 1932, Beckett took a trip which included a long walk around the northern part of the county of Dublin commonly known as Fingal, a part of the countryside then little known to Beckett. In a letter to Tom MacGreevey on the following January 5, he described the visit:

I was down at Donabate on Boxing Day and walked all about Portrane lunatic asylum in the rain. Outside the gate I was talking to a native of Lambay, and asked him about an old tower I saw in a field. 'That's where Dane Swift came to his motte' he said. 'What motte?' I said. 'Stella.' What with that and the legend about the negress that his 
valet picked up for him, and the Portrane lunatics and round tower built as relief work in the Famine, poem scum is fermenting. (Beckett, Letters 150)

The network of buildings forming the asylum at Portrane dominate the environment in the area, as Belacqua observes in "Fingal": "abstract the asylum and there was little left of Portrane but ruins" (23). The institution was founded initially as a means of relieving the overcrowding in the city centre Richmond Asylum, but by the time of its redevelopment and expansion in 1900 it had become the biggest asylum in the country and constituted the single biggest investment by the British government before political independence in 1922 (Ferlier). Beckett's encounter with one of its inmates is significant as it raises the figure of Jonathan Swift, on whom he had already been thinking following a visit to Joseph Hone and Mario Rossi, who were completing a biography of the Dean at the time (Letters 150-1). The apocryphal story that one of the towers, more than likely Portrane Castle, (or "Stella's Tower") was used by Swift as a secret meeting place for trysts with Esther Johnson provides a historic parallel for the themes of sexual desire, sexual frustration, and sexual consummation which run through the whole of "Fingal". In the story, Beckett alters the words of the man telling the story so that Swift doesn't merely "visit" Stella, but appears to keep her imprisoned there. Pointing to one of the towers he declares of "the Dane" that "he kep a motte in it" (25), echoing the themes of coercion and incarceration with which the story is concerned. Referencing Swift here in the context of Portrane almost inevitably raises the role which the Dean of St. Patrick's played in the history of the provision of institutional care for the insane in Ireland. Beckett would have been as aware as any Dubliner that Swift had left money in his will for the foundation of St. Patrick's Hospital, still in existence today, and to which Beckett's cousin Peter became professor of psychiatry (see Kelly 20-22; 240).

Unlike its appearance in the later works, in "Fingal" the role of the asylum, and in particular its inhabitants, is as a backdrop to the narrative as it relates to the narcissistic Belacqua and his difficult relationships with women. In this case, the asylum, the behaviour of the inmates, and ultimately the intervention of the psychiatrist who works there, provide a means by which the protagonist can raise the possibility of developing a meaningful relationship with a woman, Winnie Coates (a pun on the name of British psychoanalyst, Donald Winnicott), only to reject it and make good an escape. Ostensibly, the narrative describes a day out by the young couple in the countryside, but the background is heavily inflected by Freudian overtones and failed sexual encounters, no doubt suggested by the presence of the asylum and enhanced by the introduction of the figure of Dr Sholto, the psychiatrist. Much play is made of the fact that Portrane is "as full of towers as Dun Laoghaire is full of steeples" (20), suggesting an earthier collection of phallic symbols in contrast to the religiously inflected implications of those from near his home. There is a suggestion that Belacqua and Winnie have sexual relations first at the top of Feltrim Hill and later at the top of one of the towers, as in both cases Belacqua is describes as becoming 'a sad animal' $(17 ; 21)$, implying post-coital gloom. The sudden appearance of the inmates of the asylum, referred to as "the loonies" (22), the introduction of the "man from Lambay" who tells Winnie exactly the same story which Beckett was told in his own travels, and the appearance of Sholto, provide an opportunity for Belacqua to escape the scene and abandon the woman. However, in doing so, Beckett depicts Belacqua as morphing into a version of Swift, a "Little fat Presto ... like camomile" (26). This is a direct reference to Swift's description of himself in his Journal to Stella (Pilling 153).

It is quite clear that the sexual anxiety attached to Belacqua's relationship with Winnie is foregrounded by the setting of the Portrane asylum and the person of Sholto, as it presents a type of ménage à trois in which one of the protagonists will lose out. Beckett highlighted this arrangement in the poem "Sanies I", which he wrote immediately after "Fingal", and which 
drew on a second bicycle trip to the same area (Poems 275). This poem covers much of the anxiety and landscape of "Fingal" but deepens the resonance of the Swift connection by noting the make of the bike which he uses is a "Swift" (Poems 13). A draft version of this poem, entitled "WEG DU EINZIGE!", includes a scornful end-section addressed to a lost lover, which Lawlor and Pilling rightly conclude is a reference to Beckett's discovery that his university friends Ethna Mac Carthy, to whom he was attracted, and A.J. Leventhal, were romantically involved (Poems 274). The parallels with the domestic situation of Swift, in which he was said to have continued an intimate affair with two women, Stella and Esther Van Homrigh (usually known as Vanessa), are inescapable, albeit in Beckett's case two men were rivals for one woman. These details of Swift's life were particularly current at the time. Apart from Hone and Rossi's previously mentioned work, which was published a year later in 1934, biographies of the Dean were launched by Shane Leslie (1928), Carl Van Doren (1930) and Stephen Gwynne (1933), and plays on the subject by Arthur Power and W.B. Yeats premiered at the Abbey Theatre in 1927 and 1930 respectively (see Whelan 152-3). Much of the interest in these works concerns the geography of the intimate relationships between Swift and the two women. Lord Longford's play Yahoo, written at the same time as Fingal and Sanies I, hinges completely on the ménage (see Whelan 153-4). Beckett's ready association of Swift with romantic triangles seems to have persisted throughout his life, as in his later play on the theme Play (1963), which drew from his own affair with Barbara Bray, and was written while Bray was herself writing a play about Swift's triangular relationship (see Kędzierski 893).

In essence, the portrayal of the asylum and the inmates in Fingal does not constitute anything like a sustained representation of the treatment of the insane, or of the ostracised, which Beckett would provide in subsequent works. The focus is on and his sexual anxiety, leaving the vague resonance of sexual incarceration and Swift as deep-lying background noise. However, much in the same way that he describes the mixture of experiences in his visit as leading to the poetic "scum fermenting", a process in which salacious detail is brewed with historical memory and male anxiety, it is apparent that the association of Swift with the treatment of the insane and their incarceration was a trope to which he would return in the subsequent examples of Murphy and Malone Dies, and would remain present throughout his life.

\section{Murphy}

Murphy is ostensibly a tale of alien displacement and exile as it deals with the plight of an Irishman in the traditional exile of London, his alienation in that environment and the various unsuccessful means employed to return him "home" to Ireland. Beckett deals with the contradictory nature of the term asylum as a place of refuge by reflecting on the traditional depiction of the emigrant, or at least the Irish emigrant, as someone who finds both sanctuary and isolated misery in a new life outside of his home environs. Murphy reflects on the poverty of his London surroundings and compares them with a remembered, but not fully detailed, life he appears to have had in Paris: "while Brewery Road was by no means a Boulevard de Clichy nor even des Batignoles, still it was better at the end of the hill than either of those, as asylum (after a point) is better than exile" (48). Here, the very idea of asylum is a dubious blessing, as the best that can be said for it is that it dulls the effects of exile, even though he is ignoring the fact that he is in exile from home (Ireland) and his preferred place of living (Paris). In form, the narrative is a very Swiftian satire as it deals primarily in opposites of representation: Murphy is a thoughtful, laconic Irishman who is perceived as being stupid by unintelligent locals: 
'E ain't smart', said the chandler, 'not by a long chork 'e ain't.' ... 'E don't look rightly human to me,' said the chandler's eldest waste product, 'not rightly.' (50)

In much the same way, Beckett was "infuriated by the patronising English habit of addressing him in the pubs and shops as "Pat" or "Paddy"" (Knowlson 186). Murphy, as Declan Kiberd observes, "appears to English onlookers as a bedraggled moron, all body, but his real problem is that he is to himself all mind" (35).

From the beginning, Murphy displays a knowledge of, and interest in, the existing architecture of mental health treatment. When Murphy's old teacher Neary bares his head in the GPO in Dublin and rushes the statue of Cuchulainn, to "dash his head against the buttocks, such as they are" (229), Beckett makes a political comment on the realities of the Free State, as many have suggested (see Bixby 3). Yet, the means by which he escapes arrest invokes the system of mental health provision in Ireland at the time in a nuanced way. Wylie intervenes on Neary's behalf explaining cryptically that his friend is from "John o' God's. Hundred per cent harmless" and is an inmate of "Stillorgan ... Not Dundrum" (29). The two institutions cited here are the House of St. John of God in Stillorgan, near Beckett's home in Foxrock, and the Central Criminal Lunatic Asylum (now the Central Mental Hospital in Dundrum). As might be expected, the institution in Dundrum, which was opened in 1850, is linked to the criminal justice system, and therefore raises immediate questions around its appropriation of the term asylum, given that its function is primarily incarceration (Prior xxii). The House of St. John of God, by contrast, was a private psychiatric hospital, founded in 1882, and recognised by the Royal Medico-Psychological Association in 1926 (see O'Brien 242-3).

In providing such a detailed description of the levels of detention and treatment of the insane, Beckett constructs a framework and context for the central section of the narrative, which will deal with Murphy's employment in the mental institution. The asylum which employs the protagonist appears to be a thinly disguised depiction of Bethlem Hospital, which he had visited (Knowlson 69; 71). The name of the fictitious hospital offers a comic inversion of the official title of its real counterpart, so that St Mary Bethlehem Mental Asylum becomes the Magdalen Mental Mercyseat, with the Virgin Mary replaced by Mary Magdalen, and Bethlehem, the traditional birthplace of Jesus, swapped with the "Mercyseat" the seat on which God was enthroned ("Mercyseat"). However, Beckett's title offers further resonances, as it suggests the interconnection of madness, confinement and sexual transgression through its association with the system of Magdalen Asylums and Laundries which existed throughout the United Kingdom and Ireland from the eighteenth to the late twentieth centuries. These were places to which unmarried pregnant women were sent, usually giving up their babies for adoption only to continue as residents, working as virtual slave labour, in many cases for the rest of their lives (see J. Smith 212). The network of institutions formed "a vast system of increasingly punitive institutions' whose function was as much 'to hide women as the shamed others of the nation" as Clara Fischer describes it, as it was to provide support to the mothers and children (824). Such "asylums" would have been well known to Beckett, in particular, the institution in Dún Laoghaire, close to his home, titled the "Sisters of Mercy Magdalene Laundry" ("Dun Laoghaire"). In essence then, the institution which Beckett describes in the MMM is not merely a parody of the Bedlam hospital which he knew from having accompanied Geoffrey Thompson on his ward rounds, it raises the actuality of the Irish state's practice of the confinement of women related to sexual indiscretion, and forms a further meditation on the anxieties raised by his depiction of Portrane in Fingal. While the patients Murphy encounters in the MMM are not directly concerned with sexual transgression, largely deemed the prerogative of Irish women, the institution's name persists in making a link between Swift and Stella's choreography of sexual confinement and the work of Portrane. 
In essence, the portrayal of the Mercyseat is a satiric representation of eighteenthcentury Bedlam and its contemporary counterpart. Beckett reiterates the connection when describing the "single rooms, or some would say cells, or as Boswell said, mansions" (105). Frederik Smith has sourced the particular reference to a description of a visit to Bedlam by Boswell and Johnson in the Life, which Beckett marked as he was reading background material for his abandoned play on Dr Johnson Human Wishes in 1937. Beckett wrote in his notebook, "He calls the cells of Bedlam mansions (and the corridors galleries)" (F. Smith 24), underlining the incongruity of the description. At the heart of the depiction of the treatment within the hospital is a similar incongruity in which the attitude of the permanent staff is contrasted with that of Murphy. For both parties, there is a recognition that the patients are in some way "cut off" from the reality of the rest of society, however the permanent staff determine to find way to "bridge the gap" from the "private little dungheap to the glorious world of discrete particles" in order to successfully treat them (111). For Murphy, it is this very retreat to themselves which allows the patient to progress as individuals: he calls "sanctuary what the psychiatrists call exile" (111-2). Consequently his "success with the patients was little short of scandalous" (114). Unlike his superior Ticklepenny, or the Clinch clan who preside over the inmates, he achieves this through an attempt to understand them, or at least through a recognition, a sympathetic/empathetic response to their conditions.

The idea of "asylum" which is raised and questioned in "Fingal" is meditated on more deeply in Murphy and broadened to include the relationship between the connected ideas of exile, sanctuary and asylum. After all, Murphy is a geographical and political exile, by virtue of being a displaced Irishman, but assumes a position of control over the inmates, in particular, Mr Endon, with whom he develops a "relationship", albeit one which is really only conducted by means of a lengthy chess game which fails to even follow the game's rules. By becoming a keeper in the institution, Murphy finds a form of sanctuary, away from the strained home relationship with his lover Celia, inhabiting the room he occupies while on work duty. Given the ambiguities which Beckett flags for the term "sanctuary" however, it is also the case that Murphy is in many ways confined by his employment, performing an almost slave role to a surrogate master in Ticklepenny and by inhabiting a room which is accessible only through a trapdoor. Most importantly, however, is the hypothesis that Murphy is a mere mirror image of the inmates he tends to, in particular of Mr Endon, much in the same way as Beckett saw himself a "loony" among the "loonies" who he observed in Bedlam. In the course of the chess game which the men play, the difference between the men becomes erased until Murphy achieves a oneness with Mr Endon when he tucks him into bed with an intimacy which leaves them on the verge of "a butterfly kiss" (156), with the former gazing into the latter's open-eyed stare. The only difference discernible between the two is the emptiness of Endon's gaze and Murphy's vision of himself in the man's blank eyes prompting the conjecture: "Mr Murphy is a speck in Mr Endon's unseen" (156). But eventually, Murphy joins Mr Endon and becomes remembered "with pity, derision, contempt, and a touch of awe, as the male nurse that went mad with his colours nailed to the mast" (155).

Invoking Bedlam raises the echo of Swift when it is recalled that he had been elected a governor of the hospital in 1714 (Ehrenpreis 817). Beckett reinforces the allusion when Murphy turns up for work for the first time in uniform, "[f]eeling the same old Wood's halfpenny in the regulation shirt and suit" (107). On a superficial level, this describes Murphy's feelings of being an impostor and no better than the brass coin which was imposed on Ireland in the eighteenth century, and the campaign against which Swift was so strongly associated (Ehrenpreis 187-206). Swift's involvement in the resistance campaign particularly current in the 1920s and 1930s, being widely referenced by those who would promote Swift in Ireland as a protonationalist (see Mahony 148-156). A further obscure reference to Swift, and in particular his connection to the promotion of a more humane method of treatment for 
the insane, comes with the description of the attending Dr Killiecrankie as a "devout Mottist" (161). This echoes the observations ascribed to Swift's printer, Benjamin Motte and described by Kelly as "prais[ing] Swift's benevolent intentions but warn[ing] sternly against permitting the kinds of abuses and maltreatments reported in English private asylums at the time" (21).

However, it is the love/sexual relationship underpinning Murphy which is probably the most evocative Swiftian element within the narrative. As in "Fingal" there is a triangular relationship involved, as Murphy abandons Ireland in order to escape the love of Miss Counihan, ending up in London in the company of Celia. In each case, Murphy's relationship involves a degree of repulsion, despite the devotion of each of the women involved. When asked of his intimacy with Miss Counihan he answers almost in disgust: "Precordial ... rather than cordial. Tired. Cork county. Depraved" (6). Despite Celia's devotion to Murphy, he is physically repulsed by her domesticity, declaring "women are all the bloody same, ... can't love for five minutes without wanting it abolished in brats and house bloody wifery" (26). The paradox of repulsion of women at the very moment of sexual attraction is a strong trope in Swift and is most readily visible in his "The Lady's Dressing Room" (1732) and "The Progress of Beauty" (1719). In both poems, a central female figure, significantly named Celia, is observed in the moment of disrobing, thereby transforming her attractive self into a grotesque. In the latter poem, the body visibly disintegrates as its cosmetic additions are withdrawn before bed, while in the former, the idealised beauty is punctured by the interference of its bodily reality, with the revelation that "Celia, Celia, Celia shits!" (451). By calling his protagonist Celia, Beckett not also draws attention to the sexual anxiety towards the body which also permeates Swift's work, but he reprises the evocation of the ménage à trois motif which was formulated in "Fingal".

\section{Malone Dies}

In Malone Dies, Beckett revisits the interior of the asylum, again evoking Swift and a problematical sexual relationship, yet on this occasion the narrative provides for a much clearer and lengthier meditation on the broader nature of the institutional asylum as a locus of a system of power. Whereas previously the focus had been trained on the effect of the asylum on the individual, here Beckett also addresses the very nature of the power dynamic of that institution in a broader societal sense by describing the internal structural workings of the prosecution of that power and by depicting the results of its interaction with the outside, "normal" world. As the bed-ridden Malone continues to write in his decline towards death, his creation, Macmann, shares his creator's sense of confinement as, he finds himself incarcerated in an asylum. Unlike the parallel descriptions of the asylums in "Fingal" and Murphy, in this case the focus is on Macmann, the central figure of the narrative, and it is through him the narrative is observed. In this setting, Beckett provides an illustration of Foucault's analysis of "disciplinary power" in the performance of psychiatric medicine, and how this underpins an overall understanding the whole of "the mechanism of psychiatry" (41). For Foucault, the root to understanding the function of psychiatry is to be found in its performance of its power and conferred authority, and not in either an analysis of the discourse of psychiatry itself, nor in a mere analysis of the institution itself. What is important for Beckett in Malone Dies is not merely the plight of Macmann, or how the asylum "behaves", rather it is the performance of the authority within the asylum, the performance of "disciplinary power", until the disintegrating narrative provides a critique of that power's stability.

The description of this place of incarceration differs from its predecessors by providing a more ambiguous setting, allowing for a more layered rehearsal of the central theme. Portrane Hospital is only seen from the outside in "Fingal", and merely provides a background (quite literally) to the narrative which takes place outside its walls. The fictitious 
Mercyseat is drawn in more detail, and from within its walls, but provides a fantasized depiction of a reality, in keeping with the exaggerated tone of the comedy/satire of the rest of Murphy. By virtue of its existence in reality (like Portrane) while being set in a fantasy (like Mercyseat), the House of St John of God occupies an ambiguous space from the beginning. The descriptions of its grounds mirrors those of its actual counterpart in Stillorgan, South Dublin, as the reader of Murphy already knows from the reference made in the incident in the GPO, but at all times they are portrayed as a place apart. When Macmann goes missing from his cell he roams the gardens until found in what he describes as "a genuine English park, though far from England" (105), a description which calls to mind the specific isolation of exile experienced by Murphy in London specifically in the Mercyseat. However, as this sense of displacement is replicated in the Dublin setting of the House of Saint John of God (if the reader recognizes the building) or at least in a setting which appears to be one place when in fact it is somewhere else (English, though not in England) there is already a more heightened sense of dislocation which complicates the already-loaded proposition of an asylum as site of both sanctuary and abandonment. Equally, an ambiguity is suggested in the nature of the institution and particularly its grounds as one of confinement. In a lengthy passage describing the grounds, it is apparent that the role of the institution is to contain its patients as the hustle and bustle of the scene is described as "the keepers coming and going, perhaps mingled with I was going to say with the prisoners!" (108) yet when Macmann is offered the opportunity to escape through the open gates, suggesting a somewhat relaxed regime, he fails to take advantage and merely returns to the main building until he feels the relief of "the sense of absence, and the captive things beg[inning] to murmur again" (109).

A grotesque and prolonged sexual encounter appears at the heart of Macmann's narrative, echoing those in Murphy and "Fingal" but in this case, the protagonist can have no agency in the relationship as it is forced on him by, Moll, a warder/keeper, possibly with the connivance of the medical staff. The descriptions of their couplings become increasingly repulsive but in the end, Macmann is only capable of seeing them in terms of an abusive power which brutalizes him emotionally, demeaning his self-esteem and worth, to the point that "he even carried his inconsequence to the length of wondering what right anyone had to take care of him" (95). Unlike the previous conundrums and sexual anxiety abounding in Beckett's narratives, Macmann's encounter is wholly a product of his incarceration, and is merely one of the manifestations of the power wielded within it. In "Fingal", the sexual ménage of Sholto, Belacqua and Winnie is resolved by Bel running away, while the complicated sexual relations of Murphy, Celia and Miss Counihan, are only resolved as a result of Murphy's death. The sexual anxiety which abounds throughout these narratives is significantly set in relation to the asylums and their workings but are only vaguely connected. In Malone Dies, however, the anxiety is part of the process of their function.

The mirroring of an apparently insane attendant with an apparently sane inmate which underpinned the narrative of the Mercyeseat is replicated through the appearance of Lemuel keeper, and his interactions with Macmann. Lemuel is initially described as "slightly more stupid than malevolent" (96), but the description of his actions marks him as someone whose behaviour mimics that of an inmate: he is seen silent and "motionless or if you prefer scratching his head or his armpit" or crying "stamping the ground with indescribable nervousness" (96). Macmann's story, as the subject of Malone's narrative, is given privilege over Lemuel's in contrast to the treatment of Mr Endon's in Murphy and, as such, his insanity is less obvious, beyond the fact that he is a legitimate inmate of the institution as we see him "wearing over his shirt a great striped cloak reaching down to his ankles" (105). From an early point in the story, however, both men mirror each other in behaviour and action, most notably when Macmann is in the habit of going absent without leave in the gardens. It is Lemuel alone who knows where to find Macmann, and it is there they commune, after a 
fashion: "often the two of them remained there for some time, in the bush, before going in, huddled together, for the lair was small, saying nothing, perhaps listening to the noises of the night" (105). The portrayal of the two as possible reflections of the other may superficially echo the recognition scene in Murphy, however the final actions of the narrative deepen Beckett's assessment of the relationship by projecting the focus from the individual to the institutional and examining the parallel in the context of the broader scope of the asylum.

The gruesome dénoument, in which an excursion to a nearby island outside the asylum ends in Lemuel murdering everyone except the inmates, commandeering a boat and setting it adrift with all survivors including himself on board represents the last act in Malone's narration and in some ways offers a commentary on the redundancy of viewing the asylum system as a place of therapeutic value instead of merely a device of the wielding of societal power. It is significant that the trip is led by a Lady Pedal, a well-meaning Christian, as she comes to represent societal and religious hierarchical power by virtue of her title and by the overt religiosity signalled by her hymn-singing. Lady Pedal's authority is a blind one, however, as she is unable to detect the increasing menace and disruption of order during the trip when she consistently misinterprets moments of danger such as when Lemuel tells one of the companions to "Fuck off" and an inmate "utter[s] a roar", as the contrary: "a manifestation of joy" (116). Lemuel represents the authority of the asylum and is therefore deferred to by Lady Pedal, even when he behaves erratically on the island, as she declares to him "you are the one in charge" (117), and this remains the case following the attack and when he has set sail with the inmates, as the failing Malone recounts "Lemuel ...Lemuel is in charge" (119). So that what we are left with finally is the understanding that at its core the institution, through its foundation on the exercise of power over the individual, is essentially an apparatus of containment, and that its grotesque product, Lemuel, remains in authority, even at the moment of revolt and ambiguous freedom.

In naming the protagonist of the excursion scene Lemuel, Beckett clearly evokes Swift's Lemuel Gulliver, hero of his Travels. The connection is not straightforward, however, as it must be remembered that Swift's Lemuel goes mad following his adventures, his periods of exile having brought him to an ambiguous state in which he can no longer partake in human society because of the disgust he feels for it. Swift is ambiguous about how the reader should interpret Gulliver's view, whether his insight into the human condition is a wise one, the product of a revelation, or whether he has just gone mad, in the accepted sense, because of the exposure (Gulliver 10). By the end of Malone Dies, it is impossible to distinguish the certified lunatics from their keeper Lemuel, and a certain sympathy is afforded him, despite the horror of his violence. In a way, the final scene of a boat drifting to sea, without rudder or oars, becomes an extended parody of the various voyages of his namesake in Swift's tale. Gulliver always arrives in the lands he visits by a small boat, usually by accident, having been ejected, for whatever reason, from the ship in which he had originally set sail. He becomes a ship's captain only in the fourth and final section of the book, and even then is immediately mutinied by the crew and cut adrift alone. The revelatory experiences of his voyages, therefore, always appear through happenstance, and by aimless drifting, never by design or seamanship. When he does try to navigate, as in his voyage from the land of the Houyhnhnms, he always makes miscalculations and is rescued by accident, never by design.

\section{Conclusions}

Beckett displays considerable knowledge of the system of institutional mental healthcare in his allusions to Portrane, Dundrum, and the John of God's. Macmann's questions to Lemuel, in particular, are revealing: "when asked, for example, to state whether Saint John of God's was a private institution or run by the State, a hospice for the aged and the infirm or a 
madhouse, if once in one might entertain the hope of one day getting out and, in the affirmative, by what steps" (96). While there is a comic element to this, Macmann draws attention to the large variety of institutions of confinement which existed in Ireland by the 1930s. The belief that there was an ever-increasing instance of madness in the Irish population over the course of the nineteenth century is attested by two reports, in 1894 and in 1906, which both drew attention to the actuality of the increase of those declared insane in the census rose from 152 per 100,000 inhabitants in 1851 to 562 per 100,000 by 1901, leading to a commensurate rate of confinement (Prior 227). By 1845, there were eleven public and fourteen private asylums catering for 2,555 individuals. However, a waiting-list of 2,957 also existed, which was housed in a combination of jails, local asylums and, in the vast majority of cases, the poorhouses (Prior 221). The rate of increase, and the constant need to house them elsewhere explains the complicated and various means of incarceration available.

Foucault styles as "residue" those who fall outside the function of the disciplinary system which cannot accommodate them, and those who are mentally ill as "the residue of the residue", so that asylums constituted to address this element of society become a natural and self-sustaining process of the confinement of that residue (54). The process of identifying exactly what the definition of those in need of that care/confinement is necessarily dependant on the particular order of the day. Foucault also identifies that a noticeable shift in the setting of such parameters was being undertaken in the 1930s when "a critical current emerged tending towards a progressive distancing from the asylum space ... as the almost exclusive site of psychiatric intervention ... to that of a "supervised assistance"' $(59, \mathrm{n} .1)$. This process of reordering of mental health is visible in Ireland from a decision taken in 1925 in which:

All district lunatic asylums maintained by county councils under section 9 of the Local Government (Ireland) Act, 1898, shall henceforth be styled and known as district mental hospitals, and the title of every such district lunatic asylum shall be and is hereby amended by the substitution therein of the words 'mental hospital' for the words 'lunatic asylum'. (Local Government Act 79)

But it must also be borne in mind that the modes of identifying those in need of committal, the identification of the "residue", became strongly coloured by the ethos of the newly independent Free State, and in particular, its particular interest in sexual matters, sexual deviancy and the general behaviour of women. Between 1925 and 1935, as James M. Smith notes, and essentially at the prompting of the Catholic hierarchy, the state "had provoked legislation establishing censorship of films and proscribing divorce, characteristic hallmarks of the socially repressive Free State society" (208) and followed up with inquiries and legislation regarding venereal disease, censorship of literature, the status of so-called illegitimate children, the registration of maternity homes, and the codification of dance halls. Smith argues compellingly, that what he terms "Ireland's containment culture" was overwhelmingly inflected by a particular obsession with "sexual immorality", as identified in his reading of the Carrigan Report (1935), ostensibly set up to examine juvenile prostitution. For Smith, the report avoided the real issues of sexual abuse, poverty, incest and child welfare and instead arrived at a "discourse that responded to perceived sexual immorality" which "not only sanitized state policy with respect to institutional provision but also disembodied sexual practice, concealing sexual crime while simultaneously sexualizing the women and children unfortunate enough to fall victim to society's moral proscriptions" (209). In effect, the issues of dealing with Ireland's "residue" in the 1930s became heavily sexualised and heavily gendered, with the consequence that any transgression of perceived norms of sexual morality not just an affront to a religious and personal ethic, but were now an affront to the society and the state. It is unsurprising that what is apparent from the depiction of asylums in each of the 
examples chosen here is Beckett's willingness to intertwine questions of the definitions of sanity, the ambiguity of "asylum", and the complexity of sexual relations in a recurring framework that defies resolution. By referencing Swift in this context, Beckett may also be questioning the consensus that he was a straightforward champion of the Irish mad, and by extension, the oppressive "architecture of containment", as Smith describes it, so visible at the birth of the new state. The decision to muse on the inherent ambiguity is not merely personal. Beckett also negotiates the ambiguity of Swift as both self-proclaimed protector of Ireland and a figure who displays a deep mistrust of its inhabitants. In light of Smith's analysis, it is worth noting the part Swift played in the promulgation of a myth of the Irish as particularly crazy. Swift's "Verses on the Death of Dr Swift" (1731) end with the now famous quatrain: "He gave what little wealth he had/to build a house for fools and mad:/and showed in one satiric touch, /No nation wanted it so much" (Poems 498). He portrays an act of charity necessitated by the abnormal condition of the Irish, contributing to the enduring association of Ireland with madness that provided a leading rationale for the architecture of containment that followed. Meant as an ironic reflection on his whole career (he survived another fourteen years after its composition), these four lines suggest that Swift understood the problem of madness in Ireland as endemic. His pithy quatrain surfaces time and again in public discourse over the following one hundred and fifty years, bolstering the view that Ireland had a unique problem with madness, and that the solution was the incarceration of lunatics. The donation of a large sum in his will for the founding of St Patrick's undoubtedly provided a more humane regime than what had been there before, and inspired the foundation of other similar institutions, but it also consolidated the practice of associating the diagnosis and treatment of the insane with incarceration. Not unlike Lady Pedal, whose benevolence becomes her undoing, Swift might be seen as contributing to Ireland's containment culture in his very attempts to alleviate it.

\section{Works Cited}

Beckett, Samuel. The Letters of Samuel Becket. Vol. I: 1929-1940. Eds. Martha Dow Fehsenfeld and Lois More Overbeck. Cambridge: Cambridge University Press, 2009. . Murphy. Ed. J.C.C. Mays. London: Faber \& Faber, 2009.

. "Fingal". More Pricks than Kicks. Ed. Cassandra Nelson. London: Faber and Faber, 2010.

. Malone Dies. Ed. Peter Boxall. London: Faber \& Faber, 2010.

. The Collected Poems of Samuel Beckett. Eds. Seán Lawlor and John Pilling. London: Faber and Faber, 2012.

Bixby, Patrick. Samuel Beckett and the Postcolonial Novel. Cambridge: Cambridge University Press, 2009.

Ehrenpreis, Irvin. Swift: The Man, His Works, and The Age. Vol. III: Dean Swift. London: Methuen, 1983.

Ferlier, Ophélie. "St. Ita's Portrane”. National Inventory of Architectural Heritage. May 2010.1June2010.http://www.buildingsofireland.ie/Surveys/Buildings/BuildingoftheMo nth/Archive/Name, 1398,en.html

Fisher, Clara. "Gender, Nation, and the Politics of Shame: Magdalen Laundries and the Institutionalization of Feminine Transgression in Modern Ireland". Signs: Journal of Women in Culture and Society 41.4 (2016): 821-843.

Foucault, Michel. Psychiatric Power: Lectures at the Collège de France 1973-1974. Ed. Jacques Lagrange. Trans Graham Burchell. London: Picador, 2008. 
“Dun Laoghaire”. Justice for Magdalenes Research. 4 May 2019. http://www.jfmr.ie.

Kędzierski, Marek. "Barbara Bray: In Her Own Words”. Modernism/Modernity 18. 4 (2011): 887-897.

Kelly, Brendan. Hearing Voices: The History of Psychiatry in Ireland. Dublin: Irish Academic Press, 2016.

Kiberd, Declan. "Murphy and the World of Samuel Beckett". Samuel Beckett: Playwright and Poet. Ed. Christopher Murray. New York: First Pegasus, 2009. 34-47.

Knowlson, James. Damned to Fame: The Life of Samuel Beckett. London: Bloomsbury, 1996. - Beckett Remembering/Remembering Beckett. London: Bloomsbury, 2006.

Local Government Act, 1925. 24 April 2019. http://www.irishstatuebook.ie.

Mahony, Robert. Jonathan Swift: The Irish Identity. Yale: Yale University Press, 1995.

"Mercyseat". Oxford English Dictionary online edition. 1 May 2019. http://www.oed.com.

O'Brien, Eoin. The Beckett Country. Dublin: The Black Cat Press and Faber and Faber, 1986.

Pilling, John. A Strait of Two Wills: Samuel Beckett's More Pricks Than Kicks. London: Continuum, 2011.

Prior, Pauline. Introduction. Asylums, Mental Health Care and the Irish: 1800-2010. Dublin: Irish Academic Press, 2017. ix-xxiii.

. "Overseeing the Irish Asylums: The Inspectorate in Lunacy, 1845-1921". Asylums, Mental Health Care and the Irish: 1800-2010. Dublin: Irish Academic Press, 2017. 221-245.

Smith, Frederik N. Beckett's Eighteenth Century. London: Palgrave, 2002.

Smith, James M. "The Politics of Sexual Knowledge: The Origins of Ireland's Containment Culture and the Carrigan Report (1931)". Journal of the History of Sexuality 13. 2 (2004): 208-233.

Swift, Jonathan. The Complete Poems. Ed. Denis Donoghue. London: Penguin, 1983.

- Gulliver's Travels. Oxford: Oxford University Press, 2005.

Whelan, Feargal. "Lord Longford's Yahoo: An Alternative National Myth for an Alternative National Theatre". The Gate Theatre Dublin: Inspiration and Craft. Eds. David Clare, Des Lally and Patrick Lonergan. Oxford: Peter Lang, 2018. 147-160.

Feargal Whelan is a research associate at the Trinity Centre for Beckett Studies in Trinity College Dublin. He has published and presented widely on the work of Samuel Beckett and on twentieth century Irish drama. He edits the Beckett Circle and is a board member of the Samuel Beckett Society.

feargal.whelan@gmail.com 